\title{
Chinese-Foreign Cooperation in Running Schools (CFCRS): A policy analysis
}

Iftekhar, Syed Nitas

Indian Institute of Management, Kashipur, India (syed.nitas@iimkashipur.ac.in)

Kayombo, Joel Jonathan $\triangle$

Beijing Normal University, China (kayombojoel@yahoo.co.uk)

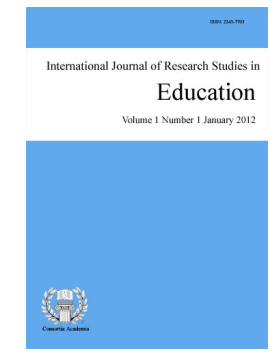

ISSN: $2243-7703$ Online ISSN: 2243-7711

OPEN ACCESS

\section{Abstract}

This study aims at analysing the Chinese-Foreign Cooperation in Running schools (CFCRS) policy in China. The two major legislative documents related to CFCRS are Interim Provisions on Chinese-Foreign Cooperation in Running Schools (1995) and the Regulations on Chinese-foreign Cooperation in Running Schools (2003). The major thrusts of these policy documents were to regulate the highly growing transnational higher education (TNHE). The analysis utilizes the Four Frame Policy Analysis Model developed by Yin Cheong Cheng and Wing Ming Cheung (1995). The Framework was used to dissect the policy process into four frames; background and underlying principles; policy formulation process; policy implementation (gaps between implementation and planning); and policy effects. Both, practical and legal challenges facing CFCRS are discussed in this analysis and suggestion for improvement are put forward. The analysis concludes by asserting that the policy has been a success though there are still some challenges and shortcomings that need to be addressed for the policy to realize the desired goals.

Keywords: policy analysis; policy process; higher education; reforms; transnational higher education; foreign cooperation; China 


\section{Chinese-Foreign Cooperation in Running Schools (CFCRS): A policy analysis}

\section{Introduction}

Since the 1980s, economic globalization has spread across the whole world gradually. People's Republic of China also witnessed economic transition from a centrally- planned economy towards a market oriented socialist economy in the post 1978 period. Its development brought remarkable impacts on education, especially the higher education. In the background of economic and educational globalization, the Chinese-Foreign Cooperation in Running Schools (CFCRS) arises at a historic moment. In late 1980s and early 1990s, international education resource was in relative surplus while the supply of domestic tertiary education resource in China was in shortage, and the development of domestic market economy surged demand for higher education, which in turn stimulated the China-foreign cooperation to start and develop (Liu, Liu, \& Qu, 2013). In line with this argument, policy makers and scholars argued that the high-quality resource of education in China was not meeting the social and economic demands, and China was in severe need of the import of high quality resource and international capital.

The Chinese Communist Party (CCP) leadership under Deng Xiaoping in 1978, initiated reforms and opening up policies, four modernizations, emphasis on economic development, and the establishment of first special economic zone in Shenzhen in 1980 for economic experimentation (Tsang, 2000). Part of the reform's focus was to develop key educational institutions at various levels. In the pursuit to show commitment to educational reforms, Deng in 1983 insisted that "education must face modernization, face the world, and face the future" (Tsang, 2000). Further reforms especially in the field of education in China were needed to cope up with the requirements of the demand and economic restructuring. China introduced a series of higher education reforms, the first reform "Outline for Education Reform and Development in China" being in 1993. This reform in 1993 identified the reduction of centralization and government control in education was issued (Cai, 2011). Since then, the continuation of reform and opening up policies even under Jiang Zemin after the demise of Deng in 1997 had tremendous positive impacts in higher education.

The reforms mainly have been driven by a few strategies in a broad perspective. The idea behind these reforms was to introduce market forces to liberate education, create impetus for change, and encourage competition for improvement of the system, and to use legislation to regulate new social relationships, practices and behaviour arising from the first strategy (Ibid). The reforms since 1993 till date are in general underlined by these strategies with emphasis on decentralisation, liberalisation, and privatisation. A series of structural reforms in curriculum design, financing, promotion of private/minban HEIs, and the quest for "world-class universities" were introduced to meet the rising demand for higher education opportunities and the state's intention of learning good practices from foreign countries.

Among the major legislative and policy documents on higher education reforms issued during this period include: 1995 Interim Provisions on Chinese-Foreign Cooperation in Running Schools; and the 2003 Regulations on Chinese-foreign Cooperation in Running Schools. The major thrusts of these policy documents were to regulate the highly growing transnational higher education. In China's context, it is called "Chinese-Foreign Cooperation in Running Schools" (CFCRS). Article 2 of the Interim Provisions for CFCRS (State Council, 1995) delineated CFCRS as educational undertakings enrolling Chinese citizens as the main objectives and run by educational institutions established in cooperation by foreign bodies corporate, individuals and relevant international organizations and Chinese educational institutions and other social organizations with the status of legal person. It was later redefined in the Article 2 of the 2003 regulation as "The activities of the cooperation between foreign educational institutions and Chinese educational institutions in establishing educational institutions within the territory of China to provide education service mainly to Chinese citizens" (State Council, 2003). 


\section{Methodology}

\subsection{Objectives}

The two policies namely Interim Provisions on CFPRS (1995) and Regulations on CFPRS (2003) both related to transnational higher education (TNHE) have been in place for almost two decades. Therefore, the study aims to analyze the CFCRS policy in China for its significance in reforming higher education in China. It is also important to analyze this policy for two reasons; for its importance in the past, and significance in shaping the future prospects of higher education in China.

\subsection{Methods}

In an attempt to analyze the CFCRS policy, the researchers adopted and combined auto ethnography and secondary research. Auto ethnography is an approach to research and writing that seeks to describe and systematically analyze personal experience in order to understand cultural experience (Ellis, Adams, \& Bochner, 2011). It is a form of self-reflection and writing that explores the researcher's personal experience and connects this autobiographical story to wider cultural, political, and social meanings and understandings (Ellis, 2004; Maréchal, 2010). Since both the researchers have lived in China and studied in Chinese higher education institutions for more than three years, their personal experiences provided an opportunity to understand higher education reforms in China particularly TNHE. Besides, secondary research and analysis was done to support researchers' auto ethnographic accounts. Secondary analysis use pre-existing data either to investigate new research questions or to re-examine primary study questions for purposes of corroboration (Heaton, 2000). In our analysis, we have therefore used published statistics, texts and media as sources of information that has helped to analyze the policy, its implementation and the resulting consequences.

\subsection{Policy Analysis Framework Model}

In this analysis of the CFCRS policy, the Four Frame Policy Analysis Model developed by Yin Cheong Cheng and Wing Ming Cheung (1995) was adapted (please see figure 1). The framework includes four sequential frames that help dissect the policy process from various stages of the policy to further analyze each section of the policy process on its own, and creating a basis for one another. The first frame focuses on analysis of the background and problems of policy and the principles underlying the setting of policy objectives and policy formulation at later stages. The background analyses helps to establish the need of the policy and the problems it was needed to address. The second frame or step in the policy analysis directs the investigation of the policy objectives, planning process, various constraints and resulting action plans. The second frame of policy formulation process provides a base for the next frame. The third frame firstly guides the analysis of the policy implementation and then identifies the gaps between implementation and planning. The difference between what was actually planned shall be compared to what actually was implemented on ground in the third phase of the methodology. The fourth frame which is equally crucial as the ones preceding it focuses on the analysis of the policy outcomes, its effects, including expected policy and educational outcomes and hidden policy outcomes at different levels. This paper shall not dwell upon the financial outcomes of the policy. It is limited to the educational outcomes at the higher education level.

\section{Major Policies on CFCRS: Introduction to the policies}

As noted earlier in this study, there are two major policies related to CFCRS namely;

$>\quad$ Interim Provisions on Chinese-Foreign Cooperation in Running Schools (1995)

$>\quad$ Regulations on Chinese-foreign Cooperation in Running Schools (2003) 
Iftekhar, S. N., \& Kayombo, J. J.

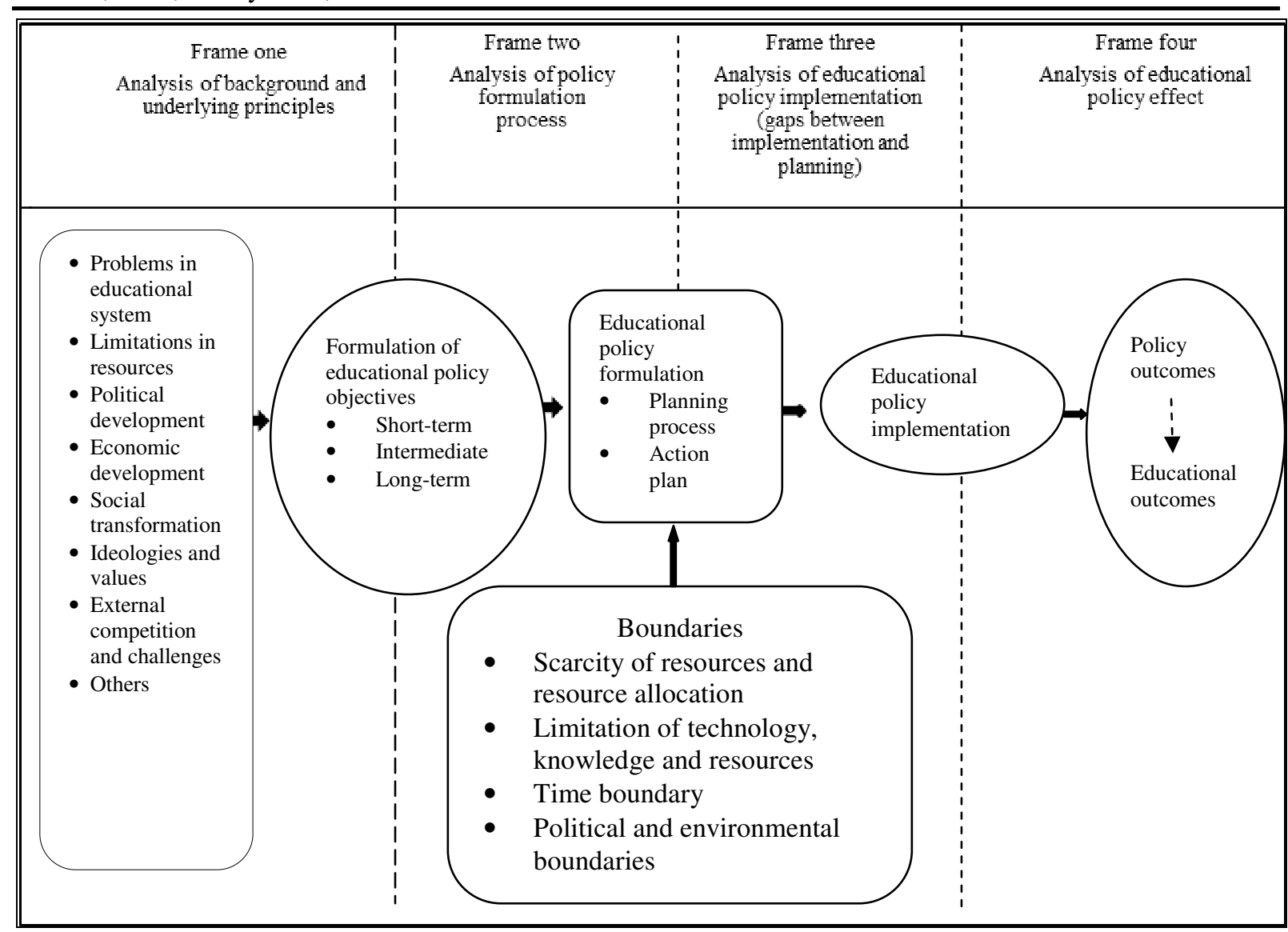

Figure 1. Four Frame Policy Analysis Model, adapted from Yin and Wing (1995, p. 11)

One of the main policy assumptions but not limited to CFCRS was that it would be a platform to provide advanced education ideas and practice within China. Foreign institutions were envisioned to contribute to the advancement of teaching methods, research and management by collaboration. This collaboration between Chinese and Foreign institutions was also expected to promote innovation as well as higher education marketability. Increase in marketability was subject to the reducing the burden on the families of students by having low fees compared to foreign universities so they had an option to send the students to study within China and get similar kind of education as compared to foreign institutions at a lower cost. CFPRS aimed to improve the level of higher education by internationalizing and attracting foreign educational resources to China.

Expansion of higher education in China meant creating more access which would provide greater financial returns. Though, that was not assumed as an objective of the policy as one of the main stipulations of the reforms on CFCRS was that partnerships must not seek profit as their objective. Yet, the 2003 legal document does not forbid overseas institutions of higher learning from making profits for running courses in China. These assumptions led to the first policy on the CFCRS in the form of Interim Provisions in 1995. In less than a decade since the first reform, in 2003 objectives set previously were reaffirmed in the Regulations on Chinese-foreign Cooperation in Running Schools (2003).

The main stipulations (in both 1995 Interim and 2003 Regulations) were:

$>\quad$ Foreign institutions must partner with Chinese institutions;

$>\quad$ Partnerships must not seek profit as their objective;

$>\quad$ No less than half of the institution governing body members must be Chinese citizens;

$>\quad$ The post of president or the equivalent must be a Chinese citizen residing in China;

$>\quad$ The basic language of instruction should be Chinese;

$>\quad$ Tuition fees may not be raised without approval.

The documents of 1995 and 2003 encouraged local universities to cooperate with renowned overseas higher 
education institutions in launching new academic programs in order to improve the quality of teaching and learning, as well as to introduce excellent overseas educational resources to local institutions (State Council, 2003, Chapter 1, Article 3). The objectives were clearly stated with a clear intent to expand Higher Education in China and create an influx for foreign resources. The transnational education has gone through "a transfer from the informal, incidental and Laissez-Fair phase prior to the more structured, systematic and well-regulated phase after 1995" (Huang, 2006).

The objectives were established on the basis of assumptions to the policy, paved way for the implementation of the policy in China. This shall be discussed in the next section under the third framework of the four-frame policy analysis model that has been adopted in this study.

\section{Approaches to policy implementation}

From the perspective of national policy, the law and the time from its formulation and implementation, the course of the development of China-foreign cooperation in running schools can be divided into three phases. The first phase which can be termed as the exploration refers to the time before the former State Education Committee publishing the Provision Regulations on Sino-foreign cooperation in Running Schools at the 26 January 1995. This phase was the root of the policy where ideas started taking concrete shape in the expansion of higher education in the form of policy in 1995.

The year 1995 was the inception of the second phase until March $1^{\text {st }}, 2003$. This phase which lasted about 8 years witnessed the implementation of the first reform on CFCRS and it is also referred to as the development phase. Developments and challenges in this phase led to the law of People's Republic of China on Sino-foreign cooperation in running schools which was issued at March $1^{\text {st }}, 2003$, as it entered into the third period from there on.

Till date CFCRS are said to be in the gradually standardised and development period (Liu et al., 2013). Similar phases of TNHE in China were propounded by Wang (2005) as (1) laissez-faire exploration, that is, before the promulgation of 'Provisional Stipulation on CFCRS' in January 1995; (2) progressive standardization: initiated by the state, that is, from 1995 to the promulgation of CFCRS Regulations in March 2003; (3) progressive legalization and regulation: advanced by the state, that is, from March 2003 onwards after the promulgation of CFCRS Regulations up to the present.

\subsection{Initial developments which paved way to policy in 1993}

In the mid-1980s, Renmin University and Fudan University of China cooperated with American educational institutions to set up curriculum about economy and law respectively. This Sino-foreign cooperation paved the way for further partnerships in the coming years. In 1986, Nanjing University-Johns Hopkins University Sino-US Cultural Center which is invested by both the Chinese and American government and universities was successfully established. Thereafter in 1988, Tianjin University of Finance and Economics cooperated with the United States Oklahoma City University to hold the MBA program which was the first Sino-foreign program to grant a foreign degree (Guo, 2012; Liu et al., 2013). The success of the co-operations was the laying stone for the CFCRS policy.

\subsection{Development since 1995}

Chinese institutions with the cooperation of foreign higher education institutions (HEIs) have developed CFCRS exponentially in China since the mid-1990s (Cai, Hölttä, \& Lindholm, 2013). In 1995, there were only two officially approved Chinese and foreign cooperative programs that could offer an overseas degree. By June 2004, the number of joint programs had increased to 754, with 169 programs qualified to award overseas degrees and around 51,000 students enrolled in them. The degree programs approved by the Chinese government were run in collaboration with 164 overseas universities and colleges (Cai, 2011). By February 2007, there were more 
Iftekhar, S. N., \& Kayombo, J. J.

than 1,400 CFCRS institutes and programs, among which 2/3 was approved by Administrative department in charge of education in the State Council and the governments at various levels (Liu et al., 2013).

The number of CFCRS institutes and programs number has been up scale with the development of the cooperation programs and institutions. Data shows that in 2010, the total number of Sino-foreign cooperation programs and institutions were more than 1,100, including 148 institutions and 951 programs, whereas the total number of students was 430,000, including 290,000 students at the stage of higher education, accounting for $1.5 \%$ of the full-time higher education students (Liu et al., 2013). The practice of Sino-foreign cooperation in running schools has made great progress after normalization of the Ministry of Education's examination and approval system. Since 2010, 114 new Sino-foreign cooperative educational institutions and programs have been approved, thereby amounting to more than 1,200 Sino-foreign cooperative institutions and programs approved by the Chinese authorities by 2013 (Ibid).

In terms of shares of countries of origin of the partnership institutions in China, Australia was leading (29.3\%) in 2004 followed by the United States (26.8\%). However, by 2007 the United Kingdom's share increased tremendously (26\%) resulting in the decline of percentage share of the United States (19\%) and Australia (15\%). Moreover, compared with the statistics from 2004, we see a rise of foreign higher education provisions in China from the UK and some other European countries such as France and Germany. In the future, it is anticipated more institutions from various countries will seek collaboration with Chinese institutions to establish more CFCRS.

\section{Findings}

The policy effects are evident in the growth of the numbers of CFCRS institutions over the years. This section evaluates and elaborates the outcomes of the policy under the fourth frame of the framework adopted in this policy analysis.

The first is that the growth rate of student enrolment in the Sino-foreign cooperation is very rapid (Brandenburg \& Zhu, 2007). Especially in most recent years, the total number of some colleges' students has already exceeded ten thousand. This has been encouraging for more domestic universities to seek for the cooperation with foreign colleges in establishing schools in China. Secondly, in the development of these kinds of cooperation, both the hardware instruments and the software construction have obtained the enormous enrichment and advancement. In some sense, Sino-foreign cooperation colleges or universities have no longer some obsolete kinds of educational institution accessories (Lin \& Liu, 2007). These schools have become an important part of college education in China, having massive professional lecturers with more international experience in higher education. Thirdly, Sino-foreign cooperation school running have come out from the stage of exchanging students or scholars. It has become an organic constituent of college education in China, playing a more important role in the world college education within China.

CFCRS has diversified higher education, providing more opportunities in education and post-education such as employment and career opportunities. Since opening up in 1978, there had been a steady development in the number of Chinese students going abroad to study. In 1984, Interim provisions on Self-funded Students Studying Abroad and in 1996, establishment of China Scholarship Council provided more opportunity and reduced restrictions thereby, increasing the total number of Chinese students studying abroad. Along with encouraging students to study abroad, China realized the need for diversifying higher education within the country so more opportunities could be created and the educational demand could also be met within the country. CFCRS has catered to the demand of education within the country by providing more opportunities and has also decreased the loss of quality students going abroad to study because of better educational opportunities.

There has been a consistent increase in the influx of international educational resources in China. CFCRS has not only encouraged Sino-foreign cooperation but it opened doors for international educational resources in China. International communication and cooperation as a result of the policy has introduced a variety of ways to 
improve standards of higher education in China. It has also provided foundation for further development and expansion of high quality international resources in China. The percentage of foreign international researchers and students has also witnessed an up-rise that can be partially attributed to the internationalization of higher education in China. By 2020, China aims to be home to more than half a million international students. CFPRS has had a major impact on higher education in China, and will continue to do so towards, achieving national targets.

\subsection{The main consequences of policy implementation}

On one hand the policies have made enormous progress and yielded positive results. It is necessary to see the picture as a whole and evaluate the shortcoming for future improvement. Despite the rapid progress in CFCRS there are many failing in the practice of Sino-foreign cooperation in running schools. From a perspective of policy analysis it is mandatory to find out the gaps in the policy process from policy assumptions and objectives to policy implementation and outcomes.

Some of the domestic colleges and universities have been focusing on the profit making in conducting cooperation in running schools. In order to charge high tuition fees in the name of cooperative education, same provinces lowered the enrolling standard, which greatly reduced the quality of students but increased enrolment in CFCRS programs (Liu et al., 2013). This was among the reason that led to suspension of approval of CFCRS programs by the Ministry of Education (MOE) between 2006 and 2010 (The Quality Assurance Agency for Higher Education, 2013). The MOE was concerned about discrepancies between what was intended in the regulation and what was happening in practice. It was observed that profit making was the motivation particularly by the less reputable foreign universities.

Secondly, although there has been a quantitative increase in CFCRS programs, the qualifications of foreign educational institutions not ensured. Some of the foreign universities are claimed to be less qualified which is against China's original intention to cooperate with renowned foreign universities and import higher education resources with high quality. Lin and Liu (2007) argued that, although some of these institutions are lawful, they are not approbated in their own countries and the students in these schools get difficult to transfer the credits they got to other schools and the diplomas students awarded in these schools are not recognized by other countries and institutions. They further attested that some foreign joint institutions were originally registered as corporations and it is difficult to distinguish their legitimacy. Although, the vast majority of the joint degree programs are provided in Chinese leading institutions, most of the foreign academic institutions interested in the "China market" are not the top institutions in their own countries (Lin \& Liu, 2007; Liu et al., 2013). As a result Chinese HEIs end up not cooperating with renowned foreign universities as envisaged in the policy.

The current system due to the loopholes discussed above cannot guarantee the introduction of foreign educational resources of high quality. According to China's WTO commitment and the Law of People's Republic of China on Sino-foreign Cooperation in Running Schools, the Sino-foreign cooperation in running schools can exist in the form of business operations, and the foreign universities can invest in and hold majority in ownership, but cannot run by themselves. However there are some good practices in CFCRS and China has seen the influx of high quality foreign educational resources. The University of Nottingham Ningbo, Shanghai New York University, Wenzhou Kean University, and Xi'an Jiaotong-Livepool University have been approved. They have independent legal personality and are the exemplary models of introducing foreign educational resources with high quality and with the whole organizational system. These universities made a good attempt in exploring a new form of Sino-foreign cooperative education (Liu et al., 2013).

\subsection{Legal challenges in CFCRS}

There is a paradox between the profit making issue and the WTO requirements. According to the regulations, "Chinese-foreign cooperation in education shall not seek profits as the objective and /or damage the state and 
public interests" (State Council, 1995, Chapter 1: Article 5). Though the documents were instituted to guarantee China's public interest, they were contrary to the motivation of foreign institutions and is not conforming to the regulations of trade and service of WTO. Article 3 (2003 Regulations) asserts that "Chinese-foreign cooperation in running schools is an undertaking beneficial to public interests and forms a component of China's educational cause". Moreover, in the document of 2003, there was not any article affirming definitely the prohibition of profit-making activities, but it still lacked articles to guide the distribution and management of the revenues and private profit of Chinese-foreign cooperative institutions (State Council, 2003). Mok (2011) argued that while prestigious HEIs develop CFCRS to expand their national and international influences, less prestigious ones do so for profits, which worry the government officials about the delivery and quality of those programs.

The main policy states that the basic language of instruction should be Chinese. According to the regulation, "A Chinese-foreign cooperatively-run school may, if necessary, use foreign languages in teaching, but shall use the standard Chinese language and standard Chinese characters as the basic teaching language" (Article 31, 2003 Regulations). Though, the policy fails to clarify what is meant by basic teaching language. The definition of "basic teaching language" remains unclear and ambiguous.

There is also a challenge of ambiguous intangible assets evaluation. The regulation stipulate that a Chinese or foreign co-operator in running a school may contribute with funds, in kind or in forms of land-use right, intellectual property rights or other assets to establish the school. Moreover it further proclaims that contribution of intellectual property rights by a Chinese or foreign co-operator in running a school shall not exceed one-third of its total contribution. However, for a foreign educational institution that comes to China for cooperation in running a school at the invitation of the education administrative department or the labour administrative department of the State Council or at the invitation of the people's government of a province, an autonomous region or a municipality directly under the Central Government, its contribution in the form of intellectual property rights may exceed one-third of its total contribution (Article 10, 2003 Regulations). In practice, there are difficulties in evaluating intangible assets like intellectual properties.

Lack of matching legal provisions and policies is another legal challenge. While one part of the article insists that the CFCRS undertakings shall be protected by the laws of China, the other paradoxically asserts that the cooperatively run schools shall enjoy preferential policies. The legal rights and interests of Chinese and foreign co-operators in running schools and of Chinese-foreign cooperatively-run schools shall be protected by the laws of China. Chinese-foreign cooperatively-run schools shall enjoy preferential policies made by the State and enjoy autonomy when conducting educational activities in accordance with law (Article 4, 2003 Regulations).

Although this form of higher education provision is regulated there is, irregularities in practices. The key weakness of the Ministry's regulatory framework is that despite a stronger emphasis on the required procedures of appraisal and approval for the CFCRS institutions and programs, less attention is paid towards the operational management of CFCRS and its quality assurance. The great variety in today's CFCRS arrangements, such as, sources of students, types of diploma/degree conferred, as well as the highly ambiguous public/private differentiation during this transitional period, have all added difficulties to the governance of TNHE in China (Mok, 2011). There is also a regulatory challenge in ensuring quality. Even though the approval from the ministry is a necessity for any CFCRS institution and program to be run formally, not all the CFCRS programs currently run by the Chinese HEIs (both public and private) are registered with the ministry (Tan, 2009). By 2009 , nearly all single-degree programs were not registered and double-degree programs from prestigious public HEIs were registered, while those from not so prestigious public HEIs were not (Mok, 2011).

\subsection{Recommendations for policy improvement}

With an Outline of National Plan for Medium and Long-term Education Reform and Development (2010-2020), CFCRS has been encouraged and there is a target of expanding it. The government expects that 
through importing international educational ideas, curricula and teaching staff more talent with international skills and perspectives will be cultivated in China to meet the needs of economic development. However, the government seeks to raise the threshold, meaning only those prestigious and high-quality foreign partners can be granted permission to China (State Council, 2010).

With regards to mobility of programs and institutes, the schools of all types and all levels should be encouraged to undertake international communication and cooperation in various forms, run several model China-foreign cooperative schools and programs, and explore a variety of ways to utilize foreign education resources. Besides, there is a need to intensively focus on developing and strengthening of quality assurance system, and introducing international high-quality resources in various channels is the key point to be considered for cross-border education in China.

For the purpose of developing and expanding TNHE as well as elevating the cooperation level, the emphasis should be put on the internationally recognized, yet relevant, and excellent cooperative partners and projects. The existing regulations and laws related to CFCRS should be perfected to create a sound institutional environment and ensure the quality of the cooperation projects. International educational capitals should be vigorously introduced and excellent imported educational resources should be explored in multiple areas.

From the financial aspect, the investment of cross-border education should be increased to improve the quality of cooperation fundamentally. Besides, the cooperative education market should be actively set up based on the volunteer and self-appraisal and while at the same time guaranteed by quality benchmark to maintain high standards. To ensure quality, the certificate of organisational self-discipline should be implemented to strengthen the admission systems and follow-up quality standards. In addition, it is necessary that the regular and systematic assessment and audit should be carried out for the approved projects and institutions (Liu et al., 2013). Regular and systemic assessment will foster and enhance the quality of the programmes.

\section{Conclusion}

CFPRS has been a break-through for China in Internationalizing their higher education and establishment of Sino-foreign co-operative schools. The benefits of these policies have been in the form of increasing access to higher education in China and catering to the rising demand of higher education. It can be asserted that it has been a success though there are still some challenges and shortcomings that need to be addressed in the coming future. Quality of education in these schools can be improved by way of superior curricula, pedagogy, administration and assessment and improved international collaboration. It will then prove to be an even more effective way to cultivate talents in the higher education system of China. It is crucial that world class quality higher education resources are imported and assimilated to meet the need of China's modernization through promoting Sino-foreign higher educational services in China.

Declaration: The authors of this paper declare that this study was not financially and materially supported by any organization.

\section{References}

Brandenburg, U., \& Zhu, J. (2007). Higher education in China in the light of massification and demographic change: Lessons to be learned for Germany. Working Paper No. 97, Centre for Higher Education Development (CHE).

Cai, Y. (2011). Chinese higher education reforms and tendencies: Implications for Norwegian higher education in cooperating with China. SIU Report Series, Vol. 4. Norwegian Centre for International Cooperation in Education (SIU).

Cai, Y., Hölttä, S., \& Lindholm, N. (2013). Establishing sub-campuses in China: A Finnish perspective, Journal 
Iftekhar, S. N., \& Kayombo, J. J.

of Research in International Education, 12(2), 142-154. http://dx.doi.org/10.1177/1475240913482834

Ellis, C. (2004). The ethnographic I: A methodological novel about autoethnography. Walnut Creek: AltaMira Press.

Ellis, C., Adams, T. E., \& Bochner, A. P. (2011). Autoethnography: An overview. Forum Qualitative Sozialforschung/Forum: Qualitative Social Research, 12(1) Art. 10.

Guo, X. (2012). Chinese-foreign cooperation in running schools and joint programs: Current status and development strategies. Paper presented at the Business and Management Education Innovation in Emerging and Developing Countries Symposium. Georgia Tech, Atlanta, US.

Heaton, J. (2000). Secondary analysis of qualitative data: A review of the literature. Full Research report ESRC 1752, Social Policy Research Unit, University of York.

Huang, F. T. (2006). Transnational higher education in mainland China: A focus on foreign degree-conferring programs. RIHE International Publication Series, 10, 21-34.

Lin, J., \& Liu, Z. (2007). Importing quality higher educational resources through Chinese-foreign cooperation in running schools. US-China Education Review 4 (3), 1-7.

Liu, B., Liu, X., \& Qu, L. (2013). Cross- border higher education in China: Development, challenges and responses. Comparative Education Bulletin, 15(1), 13-23.

Maréchal, G. (2010). Autoethnography. In A. J. Mills, G. Durepos, \& E. Wiebe (Eds.), Encyclopedia of case study research (Vol. 2, pp. 43-45). Thousand Oaks, CA: Sage Publications. http://dx.doi.org/10.4135/9781412957397.n19

Ministry of Education. (2001). Interim provisions for Chinese-foreign cooperation in running schools, China. Retrieved from http://www.edu.cn/cooperate_1406/20060323/t20060323_4010.shtml

Mok, K. H. (2011, February 28). Turning the Crisis into opportunity: Development of higher education and social harmony in China. Paper presented at the Worldwide Universities Network Virtual Seminar, University of Bristol, United Kingdom.

State Council, PRC. (1995). Interim provisions on Chinese-foreign cooperation in running schools. Retrieved from http://www.edu.cn/cooperate_1406/

State Council, PRC. (2003). Regulations of the People's Republic of China on Chinese-foreign cooperation in running schools. Retrieved from http://www.crs.jsj.edu.cn/index.php/default/news/index/3

State Council, PRC. (2010). Outline of China's national plan for medium and long-term education reform and development (2010-2020). Retrieved from http://planipolis.iiep.unesco.org/upload/China/China_National_Long_Term_Educational_Reform_Deve lopment_2010-2020_eng.pdf

Tan, Z. (2009). Internationalization of higher education in China: Chinese-foreign cooperation in running schools and the introduction of high-quality foreign educational resources. International Education Studies, 2(3), 169-171. http://dx.doi.org/10.5539/ies.v2n3p166

The Quality Assurance Agency for Higher Education. (2013). Review of UK transnational education in China: Overview. Retrieved from http://www.qaa.ac.uk

Tsang, M. C. (2000). Education and national development in China since 1949: Oscillating policies and enduring dilemmas, The China Review, 579-618. Retrieved from http://www.jstor.org/stable/23453384?seq=7\#page_scan_tab_contents

Wang, J. (2005). Transnational higher education and Chinese-Foreign cooperation in running School [in Chinese]. Shandong: Shandong Education Press.

Yin, C. C., \& Wing, M. C. (1995). A framework for the analysis of educational policies, International Journal of Educational Management, 9(6), 10-21. http://dx.doi.org/10.1108/09513549510147538 